\title{
Challenges and Prospects for Building Resilient Disease Management Strategies and Tactics for the New York Table Beet Industry
}

\author{
Sarah J. Pethybridge ${ }^{1, *(\mathbb{D})}$, Julie R. Kikkert ${ }^{2}$, Linda E. Hanson ${ }^{3}$ and Scot C. Nelson ${ }^{4}$ \\ 1 School of Integrative Plant Science, Plant Pathology \& Plant-Microbe Biology Section, \\ Cornell AgriTech at the New York State Agricultural Experiment Station, Cornell University, \\ 630 West North Street, Geneva, NY 14456, USA \\ 2 Cornell Vegetable Program, Cornell Cooperative Extension, 480 North Main Street, \\ Canandaigua, NY 14424, USA; jrk2@cornell.edu \\ 3 Sugar Beet and Bean Research Unit, United States Department of Agriculture-Agricultural Research Service \\ (USDA-ARS) and Michigan State University, 612 Wilson Road, East Lansing, MI 48824, USA; \\ linda.hanson@ars.usda.gov \\ 4 Department of Tropical Plant and Soil Sciences, College of Tropical Agriculture and Human Resources, \\ University of Hawaii at Manoa, 3190 Maile Way, Honolulu, HI 96822, USA; snelson@hawaii.edu \\ * Correspondence: sjp277@cornell.edu; Tel.: +1-315-787-2417
}

Received: 15 June 2018; Accepted: 2 July 2018; Published: 4 July 2018

\begin{abstract}
The New York table beet industry is expanding and has unique challenges to minimize crop loss in both conventional and organic production. Diseases may reduce plant population density and increase heterogeneity in a stand, reduce the duration of time foliage is healthy, and decrease the yield of marketable roots. Rhizoctonia solani Kuhn and Pythium ultimum Trow are dominant in the pathogen complex affecting crop stand and root health. Cercospora leaf spot (CLS) caused by the fungus, Cercospora beticola Sacc., is a highly destructive disease affecting foliar health. In conventional table beet production, fungicides are applied in-furrow and at emergence for early season and root disease control, and applied to foliage periodically thereafter for foliar disease control. Resistance within C. beticola populations to single-site mode-of-action fungicides poses the most significant threat to the resilience of conventional disease management. An integrated approach to reduce pesticide application when not economically warranted (i.e., a false positive) is urgently required. For foliar disease, improved scheduling of fungicides may reduce usage without loss of disease control. For soilborne diseases, pre-plant quantification of soilborne inoculum may support the selection of fields with lower inoculum densities to minimize risk of early season and root disease. For organic production, some approved products have moderate efficacy for foliar disease control, but strategies to reduce inoculum and select fields at lowest risk of disease will be paramount. Crop rotation has shown promise for disease management, but broad host range of several of the major soilborne pathogens limits the utility of this method in the production region. Enhanced knowledge of cultivar susceptibility to local populations of fungal pathogens responsible for foliar and root diseases is paramount, and adoption of commercially acceptable cultivars with improved resistance to CLS and Rhizoctonia crown and root rot has potential to transform disease management strategies for the New York table beet industry.
\end{abstract}

Keywords: Cercospora beticola; Cercospora leaf spot; epidemiology; fungicide resistance; table beet; pocket rot; Phoma betae; Pythium ultimum; red beet; Rhizoctonia solani 


\section{Introduction}

New York is a leading producer of table beet (Beta vulgaris L. spp. vulgaris: Family Chenopodiaceae) in the USA, ranking second behind Wisconsin [1], and is undergoing exponential industry growth. The industry currently supplies approximately 30,000 tons annually with an estimated worth of approximately $\$ 1.8$ million USD annually. Moreover, fresh market beets are produced on approximately 246 farms throughout the state with an estimated value of approximately $\$ 8.47$ million annually [1]. The table beet industry in New York is diverse in enterprise size and farming scale, ranging from small, diversified growers that supply farm markets and roadside stands to broad-acre fields up to approximately 45 ha in size that supply wholesale markets. Broad-acre production is for processing roots into cans and jars, direct fresh market sales, and feedstock as value-added beet products. For processing into cans and jars, the state is an important hub because of the presence of one processor, Seneca Foods. Table beet production for this market is therefore centrally located around the factory in the Mount Morris region of western New York to facilitate ease of transport of roots [2]. Table beet production in either system may be conventional and therefore able to use registered pesticides for disease and weed management. Organic table beet production is also increasing in popularity, meaning that control of weeds and diseases is restricted to only registered products approved by the Organic Materials Review Institute (OMRI; [3]).

The exponential growth of the economic value of the New York table beet industry since 2014 can continue as a function of the establishment of a new table beet processing plant in Rochester, New York for value-added products, such as snack packs and juices [4]. The growth of the industry is fueled by an enhanced awareness of the health benefits of consuming table beets and beet-based products [5]. These well-documented effects range from nutritional intervention to disease mitigation [5]. Among the most commonly reported physiological changes associated with beet consumption include improvements in cardiovascular health and sugar metabolism attributed to the rich source of dietary nitrate [6,7], the antioxidant and anti-inflammatory effects of betalains [8] and the potential to improve stamina in exercise [9]. Red table beets are also grown as the main source of betacyanins, the basis of natural coloring used to manufacture some food products [10].

The cultivation of table beet is generally restricted to temperate climates and as an annual crop for root production or a biennial for seed [11]. Beta vulgaris ssp. vulgaris is further split into six groups that also contain important arable crops. These include sugar beet produced for extraction of sugar from the roots, spinach and Swiss chard grown as leafy green vegetables, and mangelwurzel produced for fodder [11]. Production is preferred on sandy loam, silt loam or muck soil to allow root systems to expand without the physical restrictions often imposed by heavier soils [2]. A pH of at least 6.0 on mineral soils is also preferred for optimal growth. In New York, broad-acre fields are established by precision placement of seed at 38 to $76 \mathrm{~cm}$ row spacing, primarily in May and June when soil temperatures for seed germination range between 10 and $30^{\circ} \mathrm{C}$. The seed used to establish crops is a utricle and contains multiple embryos resulting from the merging of at least two flowers into a dense cluster and a corky outer rind due to the continued growth of the calyx after flowering [2,11].

Sowing depth, seed type, in-row plant density, and row spacing are important factors influencing yield and taproot size [12-16]. For example, higher in-row plant densities increase the proportion of plants with small roots but at the expense of total root yield [16,17]. Seeds of the popular cultivars used for processing are multigerm, meaning that the seed ball contains up to three seedlings ([18]; Figure 1a). In the USA, fields grown to produce table beet seed are predominantly located in three dry, temperate areas in western Washington State [19]. Seed production fields must be distant from beetroot production fields and seed production fields of other Chenopodiaceae. In this area, approximately 263 to 283 ha produces $95 \%$ of table beet seed in the USA and 50\% of production worldwide [19]. For processing, open-pollinated, red table beet cultivars such as Ruby Queen are preferred due to reduced costs for seed production, disease resistance, and optimal root characteristics for end products (e.g., taste, texture, color, nutritional value). However, there is also a broad range of table beet cultivars grown from hybrid $\left(\mathrm{F}_{1}\right)$ seed that offer advantages in vigor and more rapid growth for 
other markets [18]. These cultivars differ in optimal maturity windows, interior color (e.g., yellow, white, striped) and root shape (e.g., cylindrical, globe, flat Egyptian), crown and tap root size, foliage characteristics, color and shapes, and sugar content, ensuring that growers for fresh market sales and value-added products also have a broad selection of cultivars for different uses [18]. In broad-acre crops, foliage reaches approximately $0.5 \mathrm{~m}$ in height and canopy closure often occurs by approximately midseason (Figure 1b). Nitrogen availability and the length of the growing season also have significant effects on yield and the distribution of root sizes [20] and nutritional quality of the roots [21]. In New York, broad-acre table beet crops rarely receive supplementary water due to the frequent rainfall over spring and summer deterring growers from investigating in irrigation infrastructure [2]. However, fluctuations in water availability result in changes in the concentration of betalains (pigments) and polyphenols in the foliage. These compounds influence the transmission of solar radiation and results in increased accumulation of fiber, sugars, and minerals in the roots which reduce pre and post-processing quality [22].

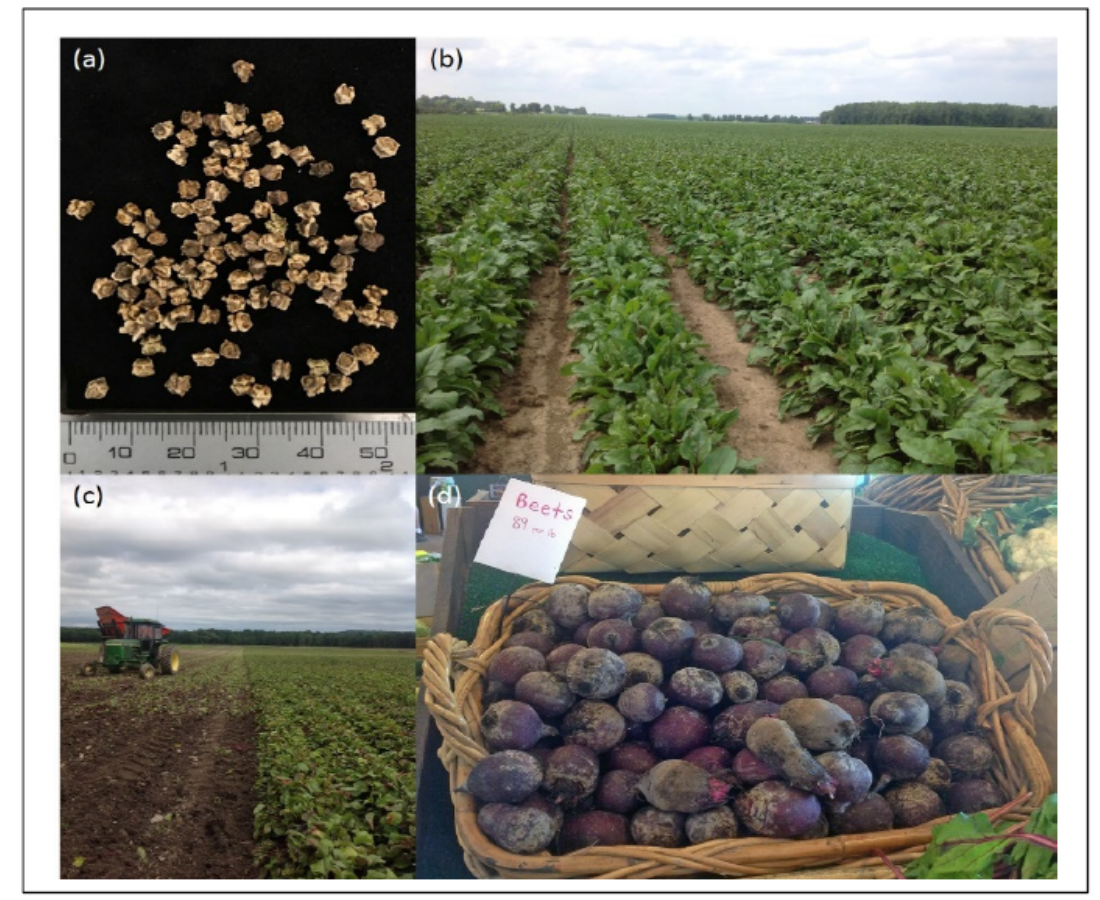

Figure 1. Parts of table beet cultivation in New York, including (a) Seed used to establish root crops; (b) Healthy foliage at approximately mid-season ( late July); (c) Harvest results in the roots being removed from the ground and return of the tops to the field; and (d) Washed table beet roots with the foliage removed for sale at a local market.

Table beet harvest occurs approximately 90 to 110 days after planting but the ability to leave the crop in the ground is beneficial for scheduling transport and processing at the factory. Storage after harvest also enables extended processing times and fresh market sales over winter [2]. In New York, the broad-acre crop is harvested using top-pulling machinery [2]. This operation pulls the roots from the ground by the foliage followed by separation of the foliage from the root at the crown (Figure 1c). The ability to harvest broad-acre table beet crops by digging in New York is limited due to rocky soils and deleterious effects on soil structure when harvest coincides with the typically high rainfall months of September to November (autumn). It is, therefore, critically important that foliage remains intact and healthy for as long as possible to enable mechanical harvesting [2]. If insufficient foliage is present or the foliage is brittle from disease or other abiotic factors such as frost, growers are at risk of complete crop loss if there is insufficient time to allow healthy foliage to regrow from the crown. Healthy foliage is also important for other markets. For fresh market sales, roots may be sold with 
foliage attached or separately (Figure 1d), and the foliage is often valued for use in salads. In this market, consumers may reject the product if the foliage has even a low number of disease lesions. In most crops, green leaf area is strongly correlated with carbohydrate production and may therefore be important in ensuring roots reach adequate size [23]. These relationships have been explored in table beet and used to model relationships between water availability, light interception, chlorophyll concentration, and photosynthetically active radiation $[22,24,25]$.

\section{Diseases Affecting Table Beet Production}

One of the major challenges in enhancing profitability, productivity and sustainability of the New York table beet industry is mitigating risk of crop loss through disease management. There are three points in production where diseases may have substantial impact on table beet yield and quality, and are therefore critical points to implement strategies and tactics for disease management. These include optimizing crop stand, maintenance of foliar health, and ensuring the production of healthy roots (Figure 2; Table 1). Yield is a direct function of the number of roots harvested per hectare, and the proportion of those roots that are of acceptable size and shape for their specific commercial use, such as canning [26]. The incidence of healthy roots that conform to specific sizes and shapes typified by a cultivar also affects economic returns to growers [2].

Table 1. Diseases affecting table beet production in New York including dominant current management strategies and control tactics.

\begin{tabular}{|c|c|c|c|c|}
\hline Disease & Pathogen & Inoculum & Management Strategies & Control Tactics \\
\hline \multicolumn{5}{|c|}{ Crop Stand } \\
\hline Damping-off & Phoma betae & $\begin{array}{c}\text { Soil and } \\
\text { infested seed }\end{array}$ & $\begin{array}{l}\text { Crop rotation and } \\
\text { certified seed }\end{array}$ & Seed treatment \\
\hline Pocket rot & Rhizoctonia solani & Soil & Crop rotation & $\begin{array}{c}\text { Seed treatment and } \\
\text { fungicide application } \\
\text { (in-furrow and early season) }\end{array}$ \\
\hline Damping-off & Pythium ultimum & Soil & Crop rotation & $\begin{array}{c}\text { Seed treatment and } \\
\text { fungicide application } \\
\text { (in-furrow and early season) }\end{array}$ \\
\hline \multicolumn{5}{|c|}{ Foliar Health } \\
\hline Bacterial leaf spot & $\begin{array}{c}\text { Pseudomonas } \\
\text { syringae pv. aptata }\end{array}$ & $\begin{array}{c}\text { Soil and } \\
\text { infested seed }\end{array}$ & Certified seed & $\begin{array}{c}\text { Pesticide applications } \\
\text { (e.g., copper-based products) } \\
\text { to foliage }\end{array}$ \\
\hline $\begin{array}{l}\text { Cercospora leaf } \\
\text { spot }\end{array}$ & Cercospora beticola & Unknown & $\begin{array}{l}\text { Crop rotation, site } \\
\text { selection, cultivar } \\
\text { selection, and burial of } \\
\text { crop residue }\end{array}$ & Foliar fungicide applications \\
\hline \multicolumn{5}{|c|}{ Root Health } \\
\hline \multirow{5}{*}{$\begin{array}{l}\text { Root disease and } \\
\text { decay }\end{array}$} & Rhizoctonia solani & Soil & $\begin{array}{l}\text { Crop rotation and } \\
\text { cultivar selection }\end{array}$ & $\begin{array}{c}\text { Fungicide application } \\
\text { (in-furrow and early season) }\end{array}$ \\
\hline & Pythium ultimum & Soil & Crop rotation & $\begin{array}{l}\text { Fungicide seed treatment } \\
\text { and in-furrow applications }\end{array}$ \\
\hline & Phoma betae & $\begin{array}{c}\text { Soil and } \\
\text { infested seed }\end{array}$ & $\begin{array}{l}\text { Crop rotation and } \\
\text { certified seed }\end{array}$ & Seed treatment \\
\hline & $\begin{array}{l}\text { Aphanomyces } \\
\text { cochlioides }\end{array}$ & Soil & Crop rotation & None \\
\hline & Fusarium spp. & Soil & Crop rotation & None \\
\hline Common scab & Streptomyces spp. & Soil & $\begin{array}{l}\text { Crop rotation, irrigation } \\
\text { scheduling, and site } \\
\text { selection }(\text { soil } \mathrm{pH}<5.2)\end{array}$ & None \\
\hline $\begin{array}{c}\text { Southern } \\
\text { Sclerotium root rot }\end{array}$ & Athelia rolfsii & Soil & $\begin{array}{c}\text { Crop rotation and site } \\
\text { selection }\end{array}$ & None \\
\hline
\end{tabular}




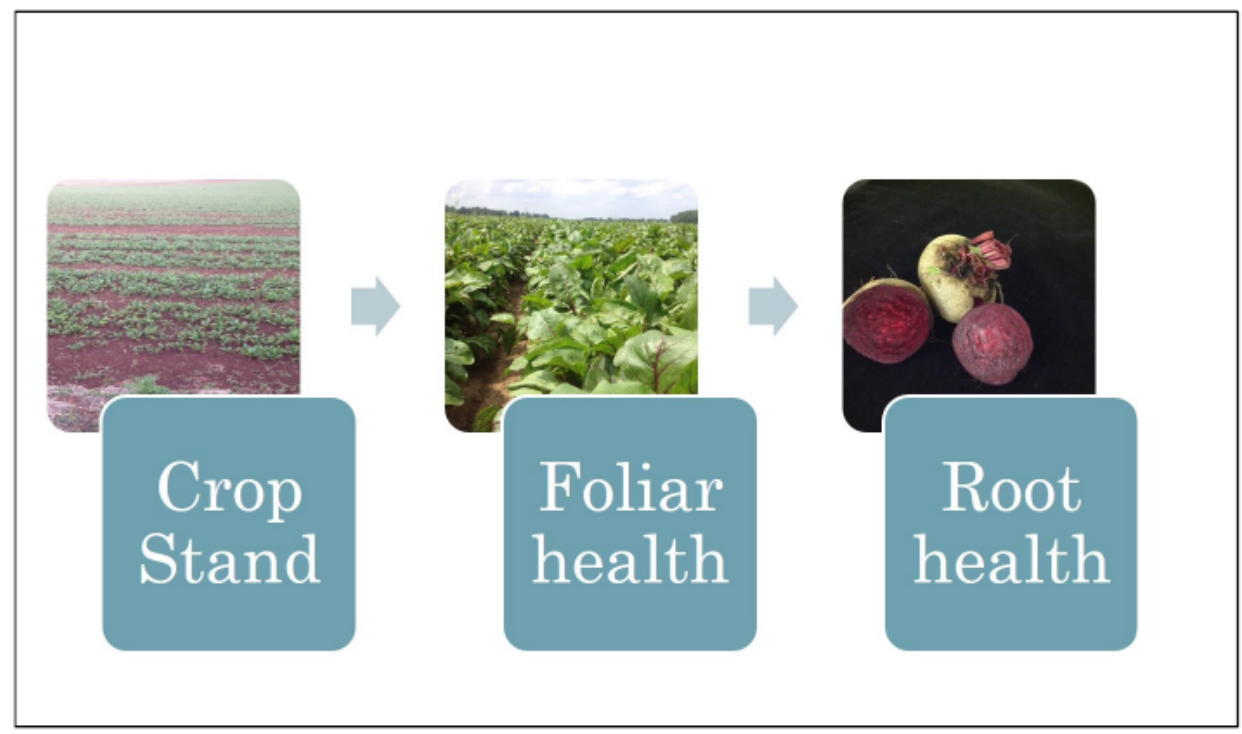

Figure 2. Critical points in the cultivation of table beet in New York at which plant diseases may significantly affect root yield and quality.

\subsection{Diseases Affecting Crop Stand}

A crop stand with an acceptable population density and homogeneous separation between plants within rows is an important determinant of table beet yield [2]. Acceptable plant density is important to ensure that attainable yield is sufficient to obtain return from investment in factors affecting profitability, such as herbicides and fungicides for weed and disease control, respectively. A homogeneous distance between seedlings in the crop stand is important as table beet roots will continue growing and taking advantage of resources such as soil moisture and nutrient availability without physical restriction from adjacent plants $[16,20]$. A homogenous crop stand therefore ensures that a higher proportion of the roots may fall within a specific size range and hence be suitable for markets such as canning [26] and snack-food containers. Other markets such as juicing and dicing may be more flexible on root size requirements.

Reductions in table beet crop stands may result from pathogens that are seedborne and soilborne ([2,27-29]; Table 1). Phoma betae Frank is the most important seedborne pathogen affecting table beet and significantly reduces germination and seedling emergence [27]. However, the use of conventional fungicides as seed treatments have substantially reduced the influence of seedborne pathogens in table beet production in New York. Reductions in crop stand from soilborne fungal pathogens, Rhizoctonia solani Kuhn and Pythium ultimum Trow causing damping-off are now therefore more significant than seedborne pathogens [28,29]. Pocket rot caused by $R$. solani tends to cause plant death in randomly distributed foci and often within poorly drained areas [29-31]. The predominant strain of $R$. solani associated with disease in table beet has been reported as anastomosis group (AG) 2-2 [30]. Pythium ultimum and $R$. solani also cause significant root disease and likely result from seedling infections that are not sufficiently severe to result in damping-off although infection later in the season can occur [27-29]. Treatment of seed with metalaxyl is the primary means of control for damping-off caused by P. ultimum. Crop loss attributable to pocket rot also significantly declined from the introduction of azoxystrobin applied in-furrow and a second application at seedling emergence [32]. The potential for selection of competitive microorganisms for the control of table beet root disease and use as a seed treatment has been suggested. For example, a Corticium spp. Sacc. with beneficial properties for the control of Pythium root rot has been described [33], and various organisms have been reported with activity against Rhizoctonia root rot [34], or a combination of these diseases [35]. In the past, this approach was not cost-effective compared to conventional fungicide seed treatments [33]. However, the lack of conventional seed treatments presents a substantial barrier to organic table beet 
production [3]. Commercial formulations of similar products such as microbial biopesticides and other products may offer viable alternatives to enhance crop stands in organic fields $[3,36,37]$. Recent findings that combined materials with different modes of action improved biological control consistency and efficacy $[36,37]$ may enhance opportunities in this area for table beet disease management.

\subsection{Diseases Affecting Foliar Health—Cercospora Leaf Spot}

In New York, a complex of fungal and bacterial diseases negatively affects the health of table beet foliage ([38,39]; Table 1). Cercospora leaf spot (CLS) is a foliar, fungal disease caused by the hemibiotroph Cercospora beticola Sacc. and is the most significant constraint responsible for annual epidemics in the majority of table beet crops [38,39]. Symptoms of CLS begin as small gray spots on the leaves and petioles that coalesce under conducive environmental conditions to encompass the leaf and result in defoliation [38]. In a red table beet cultivar CLS lesions have a red to purple margin, but in yellow and white cultivars the margin color is tan to brown (Figure 3a; [39,40]). Infection of roots [41,42] and crown lesions have been associated rarely with infection by $C$. beticola in sugar beet [43] but not reported on table beet [39]. The presence of pseudostromata (a thickened mycelial mass that gives rise to conidia) within the lesions that may be observed with a hand lens in the field is diagnostic [38]. The disease also causes significant losses to the sugar beet industry across the USA, estimated at approximately $\$ 45$ million annually, due to reduced yield and fungicide application costs [44,45].

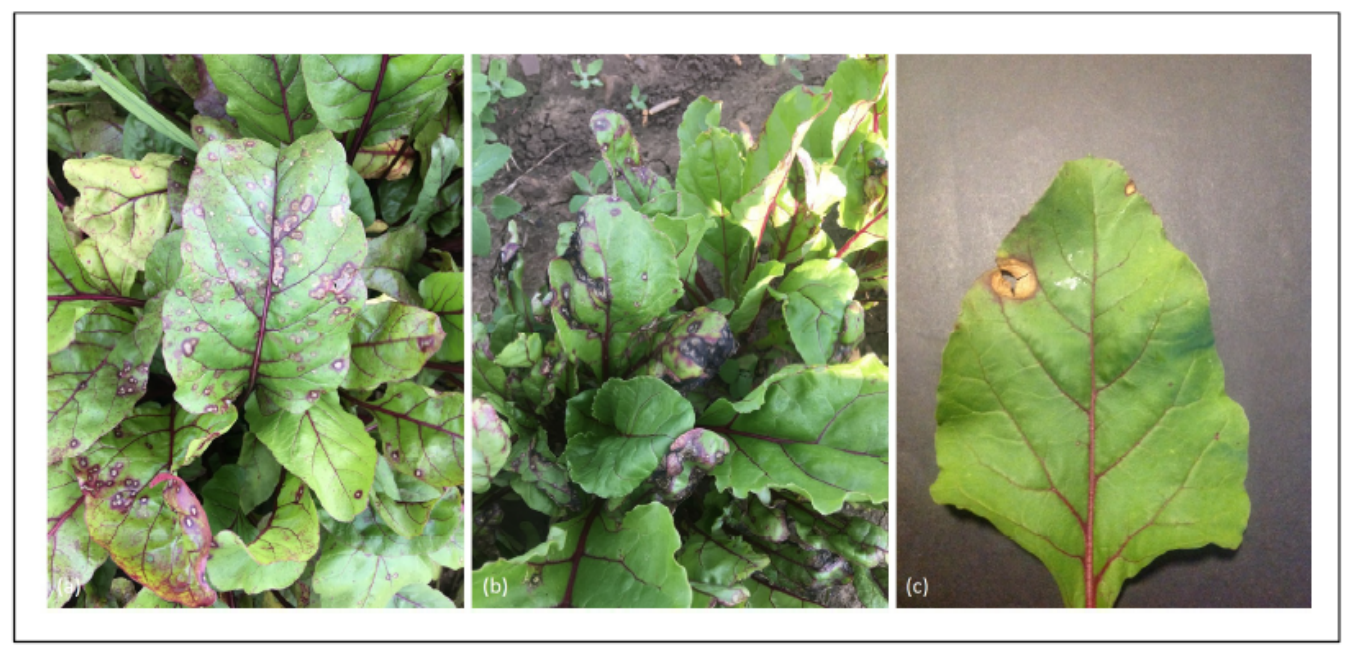

Figure 3. Foliar diseases commonly observed affecting table beet in New York: (a) Cercospora leaf spot caused by Cercospora beticola; (b) Bacterial leaf spot caused by Pseudomonas syringae pv. aptata; (c) Phoma leaf spot caused by Phoma betae.

The predominant, primary source of inoculum for CLS epidemics in New York table beet fields is largely unknown, but epidemics often begin as random foci [41,42]. Secondary spread resulting in foci expansion within a field begins when conidia are dispersed through windborne rain splash, reach the surface of the leaves, and penetrate the leaves through stomata [38]. Under conducive environmental conditions (elevated relative humidity and temperatures between 26 and $32{ }^{\circ} \mathrm{C}$ ), the CLS lesions expand and coalesce [38]. Conidia produced within the lesions enable multiple infection cycles to occur within one growing season and result in polycyclic disease epidemics [38]. The dispersal of conidia by rain splash and wind-blown rain infers short dispersal distances from 'local' inoculum within the field of interest [46-48]. Spread resulting from diseased, alternative hosts or infested crop residues within a field may also be a likely explanation for initiation of CLS epidemics as randomly distributed foci. For example, alternative hosts of $C$. beticola include crops such as spinach and Swiss chard [38] and safflower (not grown in New York; [49]), as well as various weeds [50,51]. 
Additional evidence from New York table beet fields favors the importance of external sources of inocula in the initiation of CLS epidemics. For example, no common multilocus genotypes were detected in C. beticola populations sampled from the same fields between years [52]. This finding was also supported by the identification of only C. chenopodii from CLS lesions on a common Chenopodiaceae weed, lambsquarters (Chenopodium album L.) traditionally thought to be caused by C. beticola and a dominant inoculum source for CLS epidemics in table beet [53].

The absence of a known teleomorph for $C$. beticola also adds complexity in the determination of potential sources of inoculum external to the field of interest. For example, C. beticola is heterothallic with two alternate forms of the mating-type genes (MAT1-1-1 and MAT1-2-1) that must be present for mating to occur [54-57]. Studies conducted in New York table beet fields have depicted equal distributions of the two alternate mating-type alleles, suggesting the presence of cryptic sex in the lifecycle of $C$. beticola in the region [58,59] similar to the other areas reported above. Moreover, characterization of $C$. beticola populations in these fields using microsatellite markers $[53,58]$ and genotype-by-sequencing [59] have quantified high genotypic diversity and linkage equilibrium of loci, providing further evidence in favor of sexual recombination within local populations.

In the absence of specific information on the survival of $C$. beticola in soil or infested crop residue in New York, an integrated regime of management strategies to reduce the population of within-field inocula is recommended. In the mid-western USA, C. beticola survives as stromata and mycelia in infested sugar beet crop residue for up to 22 months when on the soil surface but survival time is significantly reduced to 10 months when buried at depths of 10 and $20 \mathrm{~cm}$ [60]. Therefore, for CLS management, the burial of crop residue after harvest and a rotation of at least three years between susceptible crops such as processing spinach (also grown in western New York) may be beneficial. In small-scale, fresh market crops where table beet and other susceptible crops may be in close proximity, separation between crops may also be beneficial to prevent spread of conidia by wind-blown rain [47]. Studies evaluating genotypic diversity and genetic differentiation of $C$. beticola populations on Swiss chard and table beet in the same field have demonstrated sympatry, suggesting the absence of host differentiation and populations on either host are likely to cause disease on each other [53]. Current options to reduce CLS risk through the selection of table beet cultivars for the processing industry are limited as many end-uses such as canning, markets specify cultivar selection based on color, root shape, and sugar content preferences, limiting the options for alternative cultivars. Varying levels of intermediate cultivar resistance to CLS are reported by the table beet seed industry. However, in a study conducted in New York, with local C. beticola isolates used as inoculum, the almost exclusively used processing cultivar, Ruby Queen was the least susceptible of a selection of popular cultivars used in fresh market production including Boldor, Detroit, Falcon, Merlin, Rhonda, and Touchstone Gold [61]. However, the introgression of CLS resistance genes to table beet cultivars with commercially acceptable root shape, sugar content and color is being pursued by the vegetable seed industry and offers a valuable tool for disease management in the future.

Findings of high allelic diversity and the potential presence of sexual reproduction in the C. beticola lifecycle are also an indicator of high evolutionary risk and adaptive ability, which threatens the durability of management strategies for CLS [53,58,59]. High genetic diversity enables the pathogen populations to adapt rapidly to selection pressures such as single-site mode-of-action (MOA) fungicides [58]. Due to the high risk of crop loss from foliar disease, two to three applications of fungicides is standard as the predominant control tactic to impede CLS progression. Resistance to a single-site MOA fungicide in C. beticola populations from table beet in New York was first described following field control failures with azoxystrobin [62]. Azoxystrobin is a strobilurin fungicide belonging to the quinone outside inhibitor (QoI) group and is a member of Fungicide Resistance Action Group (FRAC) 11 [63,64]. Further studies found that of 150 C. beticola isolates collected from table beet fields with a history of azoxystrobin exposure in western New York, $41 \%$ were resistant, resulting from a G143A mutation within the cytochrome $b$ gene [58]. A single isolate with an intermediate sensitivity to azoxystrobin carried the F129L mutation within the cytochrome $b$ gene, known to be associated with 
intermediate resistance to strobilurin fungicides [58]. Subsequent surveys evaluating the sensitivity of $C$. beticola populations to azoxystrobin collected from organic and conventional table beet fields across New York have found that resistance to azoxystrobin is prevalent with up to $81 \%$ of resistant individuals within a population from a single field [65]. The use of strobilurin fungicides has been a central component for the management of CLS since their introduction in 2005 [58]. As well as being important for CLS management, azoxystrobin is the most efficacious fungicide for pocket rot control and therefore is critical for optimizing crop stand and controlling root disease [66]. There is, therefore, an urgent need to identify other means of control for both soilborne pathogens causing damping-off and root disease and CLS in conventional and organic table beet production. The identification of a fungicide belonging to a different FRAC group for use in-furrow and at seedling emergence for soilborne disease control would enable the removal or at least rotation of azoxystrobin [58]. This would decrease the risk of azoxystrobin resistance development within $R$. solani and remove the persistent selection pressure on C. beticola populations.

The prevalence of resistance to azoxystrobin within C. beticola populations also means that New York table beet growers have only one single-site MOA fungicide registered for foliar disease control. Propiconazole is a demethylation inhibitor belonging to FRAC group 3 and provides only moderate foliar disease control [39]. In vitro sensitivity testing of C. beticola populations collected in 2016 and 2017 from table beet fields across the state found a low frequency of isolates that were highly resistant, and approximately $30 \%$ that were moderately resistant to propiconazole [65]. This finding indicates a shift towards resistance in the population typical of quantitative resistance demonstrated in other plant pathogens to demethylation inhibitors [67]. Resistance to demethylation inhibitor fungicides has also been reported in C. beticola populations found on sugar beet [68-70] including on sugar beet in Ontario, Canada [71], which shares high similarity to the C. beticola population in New York [59]. This suggests that long-term use and dependence on fungicides in this class as the central tenet of a disease management program is unsustainable.

Results from small-plot, replicated efficacy trials suggested that other nonregistered products, such as a pre-mixed formulation of benzovindiflupyr and difenoconazole offer superior efficacy [39], but are at least three years from being available to New York growers pending acceptable residue testing and state registration. Other products registered for foliar disease control in New York table beet production are multi-site, copper-based protectants that offer benefits for reducing the selection pressure on a single MOA within the $C$. beticola population [58]. To achieve optimal efficacy from these products more intensive use patterns than those currently used by New York growers are required [72]. Repeated use of copper-based fungicides may also have deleterious effects on the environment due to accumulation in the soil [72]. For organic table beet production, OMRI-registered copper-based formulations offer moderate CLS control [39]. Some microbial biopesticides, such as commercial formulations of Bacillus amyloliquefaciens Priest et al. (FRAC group 44), also have moderate efficacy for the control of CLS in table beet [39]. These products therefore may offer advantages in organic and conventional systems to ensure conformity to best management practices that delay the development of resistance to single-site modes of fungicide action $[63,67]$.

Resistance to multiple modes of action within the C. beticola population also highlights the urgent need to use fungicides judiciously through improved scheduling and integration of epidemiological information to assess disease risk before applications. This may lead to reductions in fungicide usage with environmental and economic benefits and reduced exposure to pesticides when not warranted. However, complicating the decision to apply fungicides and maintain season-long disease control are inherently the risk-averse attitudes of growers due to the high economic impacts of CLS epidemics [73-75].

Forecasting systems quantify the cardinal environmental responses integrated into predictive algorithms that represent the processes regulating infection and disease development [73]. Studies on the effects of weather on infection and sporulation and the relationship between disease intensity and crop loss have led to the development of several forecasting systems for CLS in sugar beet [74-77]. 
The objective of these predictive systems is scheduling the first and/or subsequent application of fungicides to coincidence with environmental conditions that promote infection. For example, the CLS forecasting system used in sugar beet in North Dakota, USA (NDAWN; [75]) integrates in-field disease monitoring and prediction of infection events based on meteorological conditions. Disease monitoring usually begins at canopy closure ( $\sim 90 \%$ of plants from adjoining rows touching) and continues on a weekly basis [75]. The combination of temperature and rainfall data for the previous $48 \mathrm{~h}$ is expressed as daily infection values (DIVs), which range from zero to seven [75]. If the sum of DIVs from two consecutive days is less than six, equal to six, or more than six, the potential for infection is considered unfavorable, marginal, or favorable for infection, respectively [75]. The same or modified systems may also offer utility for improved CLS control in table beet in New York.

The potential for reducing the incidence of false positives for CLS control through disease forecasting systems is therefore a high priority. Adoption of forecasters by industry and growers is strongly dependent upon ease of use and clear economic benefits, such as reduced costs of production (i.e., frequency of fungicide applications) and for fungicide resistance management [73]. Many of the CLS forecasters implemented in sugar beet have further bridged the practicality gap and are publicly available, well maintained and are broadly adopted [75], and therefore serve as models for the table beet industry in New York.

\section{Other Foliar Diseases}

The prevalence, incidence and severity of other foliar diseases affecting table beet in New York fluctuate annually (Table 1). Bacterial leaf spot caused by Pseudomonas syringae Van Hall pv. aptata may be prevalent when conditions are wet and cool $\left(10\right.$ to $\left.25^{\circ} \mathrm{C}\right)$. Bacterial leaf spot lesions are black and resemble CLS lesions but lack pseudostromata $[78,79]$. The disease is most severe when plants are young (up to eight true leaves). Infected leaves appear malformed and distorted around the lesions (Figure 3b). The pathogen is seedborne in sugar beet [80] but may also be soilborne and survive on infested crop residues [78] and irrigation water [81]. Alternative hosts include Swiss chard and sugar beet [78]. Foliar sprays of copper octanoate and B. amyloliquefaciens are efficacious for the control of bacterial leaf spot in table beet in New York [82]. No information on table beet cultivar susceptibility to bacterial leaf spot is available.

Phoma leaf spot caused by the fungus, Phoma betae, is prevalent at low incidence in broad-acre, conventional table beet fields but common in fields using organic production practices (Table 1). Symptoms of Phoma leaf spot are characteristic tan to brown, large, circular lesions containing dark rings of pycnidia ([83,84]; Figure 3c). The disease may also be confused with symptoms caused by the relatively minor pathogen, Didymella americana (Morgan-Jones \& White) Chen \& Cai [85]. Phoma leaf spot is seedborne [86-88] and soilborne [89,90] and the relative contributions of these inoculum sources to epidemics in New York table beet fields are unknown. Phoma leaf spot represents a significant constraint to organic table beet production due to the absence of a thiram seed treatment [91] and alternative OMRI-registered seed treatments. Thermotherapy through hot water treatment of sugar beet seed has been effective at reducing the incidence of seedborne $P$. betae but also germination [86]. Hot water treatment or other thermotherapy conditions have not been reported for treating infested table beet seed. Infested seed may result in damping-off and thereby reduce plant density and homogeneity of the crop stand. Phoma betae is also a significant root pathogen and causes disease that initiates at the crown and is particularly problematic when roots are stored ([19,86]; Figure 3d). No information on the susceptibility of table beet cultivars used in New York to Phoma leaf spot and root rot is available.

\subsection{Root Diseases}

Root diseases are major threats to the competitiveness of the New York table beet industry. Root rots are predominantly caused by the soilborne pathogens, R. solani, P. ultimum, Phoma betae, and Aphanomyces cochlioides Drechsler ([92]; Table 1). Diseased roots cannot be used by processors or 
for fresh market sales and therefore result in direct losses to growers [2]. Affected roots may also grow abnormally and be misshapen, rendering them unsuitable for processing. At the factory, a high incidence of diseased roots means the processor incurs additional, significant costs in sorting, which is also ineffective at detecting internal rots. Losses from root diseases in storage lead to substantial decay and further direct loss and sorting costs [2].

In table beet fields in New York in 2017, mummified papery necroses (Figure 4a) associated with infection by Pythium spp. were prevalent and exacerbated by the relatively cool, wet growing conditions [92]. Symptoms caused by $R$. solani were also prevalent and manifested as depressed, black lesions often associated with longitudinal growth cracks (Figure $4 \mathrm{~b}$ ). Several Pythium spp. have been implicated in the beetroot rot complex in Queensland, Australia [93]. However, P. ultimum is the only species associated with table beetroot disease in New York [92]. An internal dry rot associated with infection by Fusarium spp. was also prevalent in 2017 (Figure 4c). In previous studies, multiple Fusarium species including F. solani (Mart.) Sacc. and F. oxysporum Schltdl. have been associated with root disease in table beet [92]. The pathogenicity of P. ultimum, and R. solani to table beet seedballs and seedlings has been demonstrated but Fusarium spp. were found to be saprophytic [92], although some are pathogenic to seedlings of other forms of beet [94], and may be to table beet as well. In table beet, symptoms caused by A. cochlioides are a scarring of the outer skin on the root, and removed in processing and hence inconsequential for this market (Figure $4 \mathrm{~d}$ ), but is an issue for fresh market.

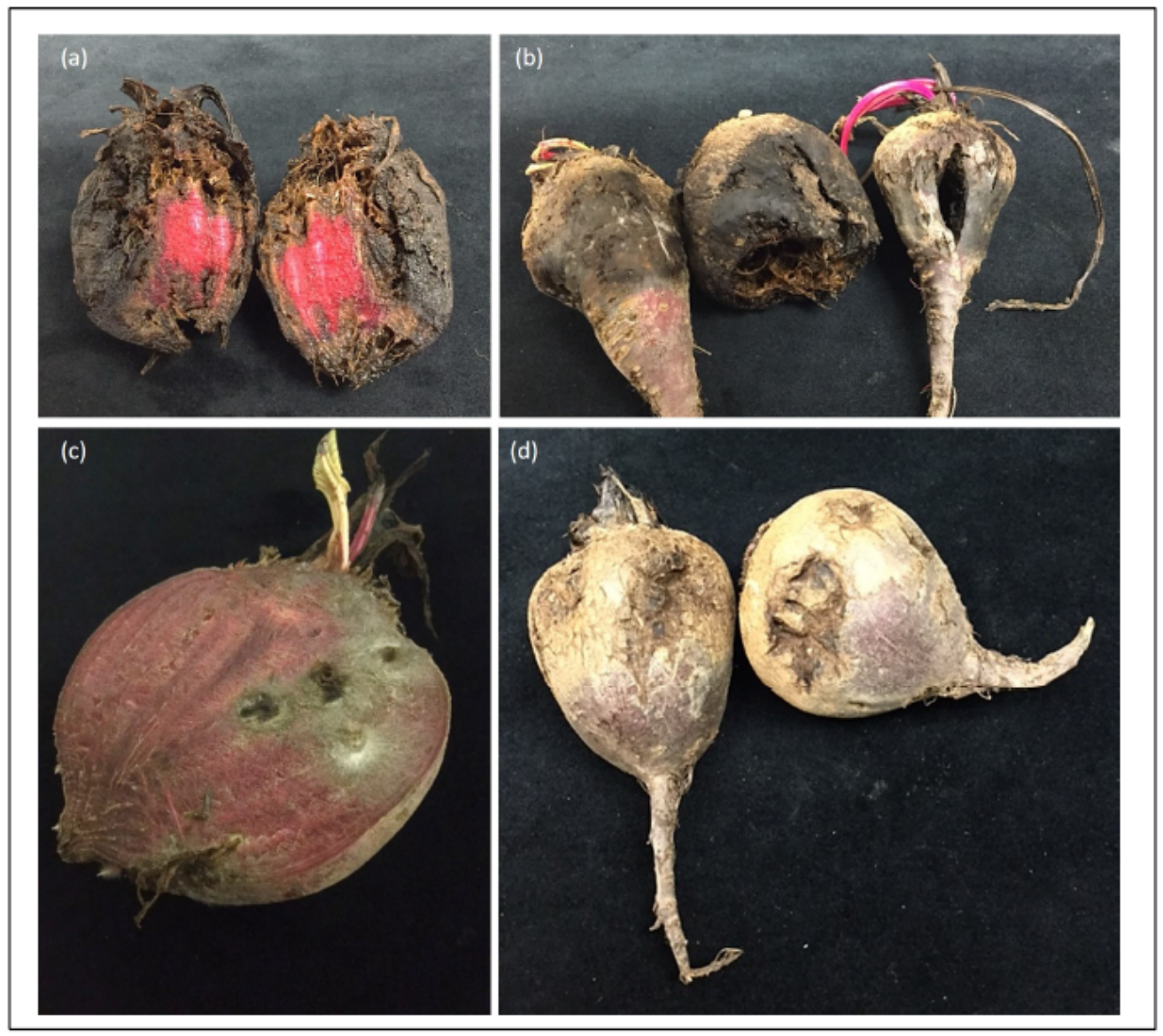

Figure 4. Table beet root disease symptoms commonly observed in New York fields: (a) Papery mummified decay caused by Pythium spp.; (b) Black rot caused by Rhizoctonia solani; (c) Dry rot caused by Fusarium spp.; and (d) Outer skin scarring caused by Aphanomyces cochlioides.

Pythium ultimum and R. solani are prevalent in New York soils and are favored by cool/wet, and warm/dry soil conditions, respectively [92]. Both species have a broad host range including 
many vegetable and field crops grown in rotation with table beet, limiting rotational options to reduce soilborne populations to mitigate risk [95]. For P. ultimum, the inclusion of metalaxyl as a seed treatment is currently the most effective control tactic. For pocket rot and root disease caused by $R$. solani, azoxystrobin in-furrow at planting and at seedling emergence is critical for achieving an acceptable crop stand [30,32]. The inability to use both pesticides in organic table beet production represents a significant constraint to ensuring adequate crop stands and healthy roots. For organic production, root disease management depends upon rotation to non-host grain crops such as wheat (Triticum aestivum L.), barley (Hordeum vulgare L.) and oats (Avena sativa L.) to reduce the soilborne populations, and the selection of sites with adequate drainage [92]. To inform these rotational choices, additional information on fecundity on different hosts is needed. Corn (Zea mays L.) has been recommended as a rotational break crop, but can be a host to some strains of Rhizoctonia solani [96]. Although the table beet cultivars Solo and Pacemaker III are reported to have intermediate resistance to Rhizoctonia crown and root rot (Sakata Seed America Inc., Morgan Hill, CA, USA), no cultivar susceptibility testing has been conducted with New York R. solani isolates. Improving the depth of knowledge surrounding table beet cultivar susceptibility to root diseases is therefore a high priority and represents a significant opportunity to reduce crop loss if a more resistant cultivar is identified.

The high risk of crop loss from root disease means that seed treatments and in-furrow applications of pesticides are prophylactic in conventional table beet production [32]. However, in many cases, risk-averse growers may apply pesticides unnecessarily and make false-positive decisions with adverse effects on crop returns, beneficial soil microorganism populations, and potential for off-site deleterious environmental effects [97]. These practices are due to the inability to adequately evaluate the population of the predominant fungal pathogens causing root disease in a timeframe of practical significance to growers. The traditional means of evaluating fungal populations in the soil are bioassays [97] or counting colony-forming units through plating to selective media. To improve site selection to mitigate risk from root diseases significant advances are possible through the provision of knowledge on the levels of DNA of the specific pathogens prior to planting [98]. DNA can be easily and rapidly extracted from soil [99] and has been used as a pre-plant predictor of risk for root crop diseases including potato $[100,101]$. The ability to extract DNA from large $(100 \mathrm{~g})$ volumes of soil also overcomes some of the shortfalls of this technique relating to ensuring a sample of sufficient size to counter inherent heterogeneity within a field [102]. Quantitative PCR can then evaluate fungal populations and provide substantial advances in enhancing our understanding of inoculum densities in the development of monocyclic, soilborne diseases. For example, in Australia, a commercial pre-plant soil testing service called "PreDicta B" has been operating for the cereal industry since 1997 [98], and quantifies several pathogens of cereals in DNA extracted from a single soil sample $[98,99]$. In this service, soil samples from across the field tested with proprietary protocols [98]. In collaboration with growers, trained extension educators then interpret the results in the context of their individual cropping systems [98]. DNA extraction from soil samples and detection and quantification by PCR offers several advantages over conventional techniques for delivery of findings in a practical timeframe to enable site-specific decisions on crop rotations [98,99,102].

Common scab, caused by Streptomyces Waksman \& Henrici species [103,104], and Southern Sclerotium root rot, caused by Athelia rolfsii (Curzi) Tu \& Kimbr. [105] are additional important soilborne diseases of table beet but are limited distribution in New York [106], and more commonly observed in diversified fresh market production systems. Damage from common scab is primarily cosmetic and results in superficial blister and scab symptoms (Figure 5a), and can result in culling of roots for sale to the fresh market. The disease is prevalent in diversified farms in eastern and northern New York where soil pH is above 5.2. In table beet, there is no known tolerance between cultivars and careful monitoring of soil $\mathrm{pH}$, avoiding low soil moisture early in crown development, and crop rotation to nonsusceptible species are the most important management strategies [104]. Initial symptoms of Sclerotium root rot in table beet fields appear as wilted plants but rapidly progresses to severe root rot and may result in substantial post-harvest decay [105]. Signs include characteristic 
white mycelial mats and the presence of profuse golden brown (1 to $2 \mathrm{~mm}$ diam.) sclerotia [105,107] (Figure 5b). Although Sclerotium root rot is currently of limited prevalence [106], the potential for spread of the disease into broad-acre table beet fields is concerning and strict farm hygiene protocols to prevent introduction are likely the most critical intervention point [107].

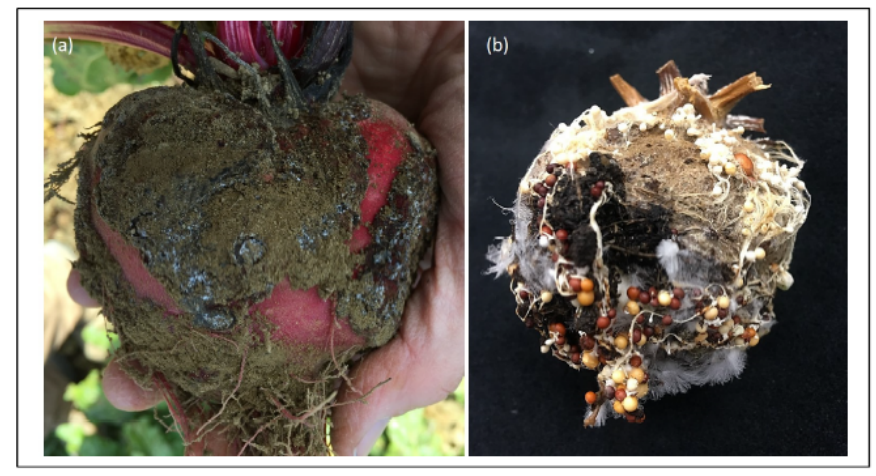

Figure 5. Symptoms of (a) Common scab caused by Streptomyces spp.; and (b) Southern Sclerotium root rot caused by Athelia rolfsii, are important soilborne diseases of table beet in New York with limited geographical distributions. Figure 5 a provided with permission by A. Ivy, Cornell Cooperative Extension, New York, USA.

\section{Conclusions and Opportunities}

Rapid expansion of the New York table beet industry brings inherent challenges and opportunities for making transformational change to productivity factors including disease management in both conventional and organic production systems. Improved management of seedborne and soilborne diseases in either system will optimize the crop stand influencing the number of acceptable roots for specific markets, and the incidence of root disease. A reduced dependence on site-specific MOA fungicides for control of soilborne and foliar diseases is essential to ensure the sustainability of the integrated disease management program. The enhanced availability of OMRI-registered pesticides including microbial biopesticides and improved copper formulations offer potential for a suite of control tactics suitable for organic table beet production and rotational benefit in conventional systems.

Opportunities also exist to reduce the dependence on fungicides for soilborne and foliar disease control and hence the deleterious effects of false positive decisions. For example, the utility of predictive systems based on environmental conditions after canopy closure have been demonstrated for CLS control in sugar beet and offer the potential for cost savings in table beet. Improved means for quantifying soilborne pathogen populations through DNA-based soil testing for early season and root diseases are also available. Other opportunities for new paradigms in disease control are likely to result from digital technologies. The ability to detect disease-specific spectral signatures earlier than the appearance of symptoms and next generation pesticides based on nanotechnology offer the ability for prescriptive approaches to disease control. Enhanced knowledge of spatial heterogeneity within fields and associations between soil properties and disease incidence opens potential for robust cost benefit analysis on site selection and within field variability in optimizing planting arrangements. Improved knowledge of table beet cultivar susceptibility to local populations of the dominant foliar and root diseases is also vital and a sentinel step in reducing the need for pesticide-based disease control. Improved host resistance could enhance all disease management.

Underpinning the adoption of these new conceptual frameworks for disease management is sentinel information on pathogen biology and epidemiology. There are still clear gaps in our foundational knowledge of the key pathogens and diseases affecting table beet in New York. For example, knowledge of the primary inoculum source for CLS epidemics and the relative contribution of within field inoculum sources (e.g., infested residues, alternative hosts) is clearly lacking. 
Additional information on the species diversity associated with the dominant root pathogens and host range would be beneficial for planning crop rotations. Similarly, the potential to use biofumigation and green manure cover crops for the control of soilborne plant pathogens would also be worthwhile.

Funding: This research was supported by the United States Department of Agriculture National Institute of Food and Agriculture Hatch project NYG-625424; the Federal Capacity Funds Initiative Project Number 2015-16-118 managed by the New York State Agricultural Experiment Station, Cornell University, New York, USA; the New York Vegetable Research Association and Council; Specialty Crop Block Grants SCG 15-002 and SCG 17-002; and USDA NIFA Crop Protection and Pest Management Award No. 2016-70006-25837.

Acknowledgments: We thank the members of our team who have contributed to our table beet disease research and extension program at Cornell University (listed alphabetically by surname): Carol Bowden, Zachariah Hansen, Traci Hoogland, Noel Knight, Lori Koenick, Elizabeth Maloney, Sean Murphy, Sandeep Sharma, Alex Silva, David Strickland, and Niloofar Vaghefi. We are also grateful to the growers, Dewey Produce, and Seneca Foods for constructive discussion and guidance, provision of land for on-farm trials, and access to fields for sample collection.

Conflicts of Interest: The authors declare no conflict of interest.

\section{References}

1. USDA-NASS. United States Department of Agriculture National Agriculture Statistics Service. 2016. Available online: https:/ / quickstats.nass.usda.gov/ (accessed on 31 March 2018).

2. Stivers, L. Crop Profile: Beets in New York. Cornell Cooperative Extension Bulletin. Available online: http:/ / pmep.cce.cornell.edu/fqpa/crop-profiles/beet.html (accessed on 25 March 2018).

3. Thakore, Y. The biopesticide market for global agricultural use. Ind. Biotechnol. 2006, 2, 194-208. [CrossRef]

4. Governor, A.M. Cuomo. Love Beets USA to be Located at Eastman Business Park. Available online: https: / / www.governor.ny.gov / news/governor-cuomo-announces-140-new-jobs-rochester-lidestri-foodsand-gs-fresh-create-partnership (accessed on 3 July 2018).

5. Clifford, T.; Howatson, G.; West, D.J.; Stevenson, E.J. The potential benefits of red beetroot supplementation in health and disease. Nutrients 2015, 7, 2801-2822. [CrossRef] [PubMed]

6. Gilchrist, M.; Winyard, P.G.; Fulford, J.; Anning, C.; Shore, A.C.; Benjamin, N. Dietary nitrate supplementation improves reaction time in type 2 diabetes: Development and application of a novel nitrate-depleted beetroot juice placebo. Nitrate Oxide 2014, 40, 67-74. [CrossRef] [PubMed]

7. Hobbs, D.A.; George, T.W.; Lovegrove, J.A. The effects of dietary nitrate on blood pressure and endothelial function: A review of human intervention studies. Nutr. Res. Rev. 2013, 26, 210-222. [CrossRef] [PubMed]

8. Georgiev, V.G.; Weber, J.; Kneschke, E.M.; Denev, P.N.; Bley, T.; Pavlov, A.I. Antioxidant activity and phenolic content of betalain extracts from intact plants and hairy root cultures of the red beetroot Beta vulgaris cv. Detroit Dark Red. Plant Foods Hum. Nutr. 2010, 65, 105-111. [CrossRef] [PubMed]

9. Vanhatalo, A.; Bailey, S.J.; Blackwell, J.R.; di Menna, F.J.; Pavey, T.G.; Wilderson, D.P.; Benjamin, N.; Winyard, P.B.; Jones, A.M. Acute and chronic effects of dietary nitrate supplementation on blood pressure and the physiological responses to moderate-intensity and incremental exercise. Am. J. Physiol. Regul. Integr. Comp. Physiol. 2010, 299, R1121-R1131. [CrossRef] [PubMed]

10. Szalaty, M. Physiological roles and bioavailability of betacyanins. Postep. Fitoter. 2008, 1, $20-25$.

11. Lewellen, R.T.; Panella, L.W.; Harveson, R. Introduction-Botany of the beet plant. In Compendium of Beet Diseases and Insects; APS Press: St. Paul, MN, USA, 2009; ISBN 978-0-89054-365-8.

12. Warne, L.G.G. Effects of close spacing on the growth of garden beet. Nature 1953, 172, 506. [CrossRef]

13. Benjamin, L.R. The relative importance of cluster size, sowing depth, time of seedling emergence, and between-plant spacing on variation in plant size in red beet (Beta vulgaris L.) crops. J. Agric. Sci. 1987, 108, 221-230. [CrossRef]

14. Benjamin, L.R.; Bell, N. The influence of seed type and plant density on variation in plant size of red beet (Beta vulgaris L.) crops. J. Agric. Sci. 1985, 105, 563-571. [CrossRef]

15. Benjamin, L.R.; Sutherland, R.A.; Senior, D. The influence of sowing rate and row spacing on the plant density and yield of red beet. J. Agric. Sci. 1985, 104, 615-624. [CrossRef]

16. Kikkert, J.R.; Reiners, S.; Gugino, B.K. Row width, population density, and harvest dates on marketable yield of table beet. HortTechnology 2010, 20, 560-567.

17. Tyler, F.T.; Adas, L.; Benjamin, L.R. Spacing red beets for high returns. Grower 1982, 97, 19-23. 
18. Becker, R. The beet goes on, this stalwart vegetable keeps getting better. Horticulture 1987, 10, 51-55.

19. Du Toit, L. Crop Profile for Table Beet Seed in Washington; Washington State University Extension Bulletin Number MISC0356E; Washington State University Press: Pullman, WA, USA, 2007.

20. Hipp, B.W. Influence of nitrogen and length of growing season on yield and size distribution of table beets. J. Am. Soc. Hortic. Sci. 1977, 102, 598-601.

21. Mampa, S.S.; Maboko, M.M.; Soundy, P.; Sivakumar, D. Nitrogen application and leaf harvesting improves yield and nutritional quality of beetroot. HortTechnology 2017, 27, 337-343. [CrossRef]

22. Stagnari, F.A.; Galieni, A.; Speca, S.; Pisante, M. Water stress effects on growth, yield and quality traits of red beet. Sci. Hortic. 2013. [CrossRef]

23. Penuelas, J.; Filella, I.; Gamon, J.A. Assessment of photosynthetic radiation-use efficiency with spectral reflectance. New Phytol. 1995, 131, 291-296. [CrossRef]

24. Stagnari, F.A.; Galieni, A.; Cafiero, G.; Pisante, M. Application of photoselective films to manipulate wavelength of transmitted radiation and photosynthate composition in red beet (Beta vulgaris var. conditiva Alef.). J. Sci. Food Agric. 2013. [CrossRef]

25. Stagnari, F.A.; Galieni, A.; Speca, S.; Cafiero, G.; Pisante, M. Effect of light and water supply on morphological and physiological leaf traits of red beet. Agron. J. 2014, 106, 459-468. [CrossRef]

26. USDA. United States Standards for Grades of Canned Beets (81 FR 93572). Effective 20 January 2017. Available online: https://www.ams.usda.gov/sites/default/files/media/CannedBeetsStandard.pdf (accessed on 28 March 2018).

27. Byford, W.J.; Gambogi, P. Phoma and other fungi on beet seed. Trans. Br. Mycol. Soc. 1985, 84, $21-28$. [CrossRef]

28. Abawi, G.S.; Crosier, D.C.; Becker, R.F. Symptomatology and etiology of root rot of table beets in New York. Phytopathology 1974, 1, 132.

29. Olaya, G.; Abawi, G.S. Occurrence of Thanatephorus cucumeris on table beets in New York State (Abstr.). Phytopathology 1991, 81, 1186.

30. Olaya, G.; Abawi, G.S. Characteristics of Rhizoctonia solani and binucleate Rhizoctonia species causing foliar blight and root rot on table beets in New York State. Plant Dis. 1994, 78, 800-804. [CrossRef]

31. Olaya, G.; Abawi, G.S. Influence of inoculum type and moisture on development of Rhizoctonia solani on foliage of table beets. Plant Dis. 1994, 78, 805-810. [CrossRef]

32. Shah, D.A.; Stivers-Young, L. Factors associated with decay in table beets identified by a statistical analysis of grower and processor records. HortTechnology 2004, 14, 25-29.

33. Hoch, H.C.; Abawi, G.S. Biological control of Pythium root rot of table beet with Corticium sp. Phytopathology 1979, 69, 417-419. [CrossRef]

34. Sadeghi, A.; Hesan, A.R.; Askari, H.; Qomi, D.N.; Farsi, M.; Hervan, E.M. Biocontrol of Rhizoctonia solani damping-off of sugar beet with native Streptomyces strains under field conditions. Biocontrol Sci. Technol. 2009, 19, 985-991. [CrossRef]

35. Webb, K.M.; Harveson, R.M.; West, M.S. Evaluation of Rhizoctonia zeae as a potential biological control option for fungal root diseases of sugar beet. Ann. Appl. Biol. 2015, 167, 67-89. [CrossRef]

36. Dube, B.; Smart, G.C. Biological control of Meloidogyne incognita by Paecilomyces lilacinus and Pasteuria penetrans. J. Nematol. 1987, 19, 222-227. [PubMed]

37. Xu, X.M.; Jeffries, P.; Pautasso, M.; Jeger, M.J. Combined use of biological control agents to management plant diseases in theory and practice. Phytopathology 2011, 101, 1024-1031. [CrossRef] [PubMed]

38. Weiland, J.; Koch, G. Sugarbeet leaf spot disease (Cercospora beticola Sacc.). Mol. Plant Pathol. 2004, 5, 157-166. [CrossRef] [PubMed]

39. Pethybridge, S.J.; Vaghefi, N.; Kikkert, J.R. Management of Cercospora leaf spot in conventional and organic table beet production. Plant Dis. 2017, 101, 1642-1651. [CrossRef]

40. McKay, M.B.; Pool, V.W. Field studies of Cercospora beticola. Phytopathology 1918, 8, 119-136.

41. Vereijssen, J.; Schneider, H.J.H.M.; Termorshuizen, A.A.J. Possible root infection of Cercospora beticola in sugar beet. Eur. J. Plant Pathol. 2004, 110, 103-106. [CrossRef]

42. Vereijssen, J.; Schneider, H.J.H.M.; Termorshuizen, A.A.J. Root infection of sugar beet by Cercospora beticola in a climate chamber and in the field. Eur. J. Plant Pathol. 2005, 112, 201-210. [CrossRef]

43. Giannopolitis, C.N. Lesions on sugar beet roots caused by Cercospora beticola. Plant Dis. Rep. 1978, 62, 424-427. 
44. Shane, W.W.; Teng, P.S. Impact of Cercospora leaf spot on root weight, sugar yield and purity of Beta vulgaris. Plant Dis. 1982, 76, 812-820. [CrossRef]

45. Wolf, P.F.J.; Weis, F.J.; Verreet, J.A. Influence of different cropping systems and threshold values on the epidemiological behaviour of Cercospora beticola in sugar beet. Meded. Fac. Landbouwkd. Toegep. Biol. Wet. 1995, 60, 431-438.

46. Lawrence, J.S.; Meredith, D.S. Wind dispersal of conidia of Cercospora beticola. Phytopathology 1970, 60, 1076-1078. [CrossRef]

47. Vereijssen, J.; Schneider, J.H.M.; Stein, A.; Jeger, M.J. Spatial pattern of Cercospora leaf spot of sugar beet in fields in long- and recently-established area. Eur. J. Plant Pathol. 2006, 116, 187-198. [CrossRef]

48. Vereijssen, J.; Schneider, J.H.; Jeger, M.J. Epidemiology of Cercospora leaf spot on sugar beet: Modeling disease dynamics within and between plants. Phytopathology 2007, 97, 1550-1557. [CrossRef] [PubMed]

49. Lartey, R.T.; Caesar-TonThat, T.C.; Caesar, A.J.; Shelver, W.L.; Sol, N.I.; Berman, J.W. Safflower: A new host of Cercospora beticola. Plant Dis. 2005, 89, 797-801. [CrossRef]

50. Groenewald, M.; Groenewald, J.Z.; Braun, U.; Crous, P. Host range of Cercospora apii and C. beticola and description of C. apiicola, a novel species from celery. Mycologia 2006, 98, 275-285. [CrossRef] [PubMed]

51. Vestal, E.F. Pathogenicity, host response and control of Cercospora leaf-spot in sugar beets. Res. Bull. 1933, 168, 43-72.

52. Knight, N.L.; Vaghefi, N.; Hansen, Z.R.; Kikkert, J.R.; Pethybridge, S.J. Temporal genetic differentiation of Cercospora beticola populations in New York table beet fields. Plant Dis. 2018. [CrossRef]

53. Vaghefi, N.; Nelson, S.C.; Kikkert, J.R.; Pethybridge, S.J. Genetic structure of Cercospora beticola populations on Beta vulgaris in New York and Hawaii. Sci. Rep. 2017, 7, 1726. [CrossRef] [PubMed]

54. Groenewald, M.; Linde, C.C.; Groenewald, J.Z.; Crous, P.W. Indirect evidence for sexual reproduction in Cercospora beticola populations from sugar beet. Plant Pathol. 2008, 57, 25-32. [CrossRef]

55. Groenewald, M.; Groenewald, J.Z.; Harrington, T.C.; Abeln, E.C.A.; Crous, P.W. Mating type gene analysis in apparently asexual Cercospora species is suggestive of cryptic sex. Fungal Genet. Biol. 2006, 43, 813-825. [CrossRef] [PubMed]

56. Bolton, M.D.; Secor, G.A.; Rivera, V.; Weiland, J.J.; Rudolph, K.; Birla, K.; Rengifo, J.; Campbell, L.G. Evaluation of the potential for sexual reproduction in field populations of Cercospora beticola from USA. Fungal Biol. 2012, 116, 511-521. [CrossRef] [PubMed]

57. Bolton, M.D.; de Jonge, R.; Inderbitzen, P.; Liu, Z.; Birla, K.; Van de Peer, Y.; Subbarao, K.V.; Thomma, B.P.H.J.; Secor, G.A. The heterothallic sugarbeet pathogen Cercospora beticola contains exon fragments of both MAT genes that are homogenized by concerted evolution. Fungal Genet. Biol. 2014, 62, 43-54. [CrossRef] [PubMed]

58. Vaghefi, N.; Hay, F.S.; Kikkert, J.R.; Pethybridge, S.J. Genotypic diversity and resistance to azoxystrobin of Cercospora beticola on processing table beet in New York. Plant Dis. 2016, 100, 1466-1473. [CrossRef]

59. Vaghefi, N.; Kikkert, J.R.; Bolton, M.D.; Hanson, L.E.; Secor, G.A.; Nelson, S.C.; Pethybridge, S.J. Global genotype flow in Cercospora beticola populations confirmed through genotyping-by sequencing. PLoS ONE 2017, 12, e0186488. [CrossRef] [PubMed]

60. Khan, J.; del Rio, L.E.; Nelson, R.; Rivera-Varas, V.; Secor, G.A.; Khan, M.F.R. Survival, dispersal and primary infection site for Cercospora beticola in sugar beet. Plant Dis. 2008, 92, 741-745. [CrossRef]

61. Pethybridge, S.J.; Vaghefi, N.; Kikkert, J.R. Horticultural characteristics and susceptibility of table beet cultivars to Cercospora leaf spot in New York. HortTechnology 2017, 27, 530-538. [CrossRef]

62. Abawi, G.S.; Kikkert, J.R.; Moktan, K.; Lange, H.W.; Smart, C.D. First report of resistance to Quadris among populations of Cercospora beticola causing leaf spot of table beet in New York State. (Abstr.) Phytopathology 2014, 104, 1.

63. Bartlett, D.W.; Clough, J.M.; Godwin, J.R.; Hall, A.A.; Hamer, M.; Parr-Dobrzanski, B. The strobilurin fungicides. Pest Manag. Sci. 2002, 58, 649-662. [CrossRef] [PubMed]

64. Fisher, N.; Meunier, B. Molecular basis of resistance to cytochrome bc inhibitors. FEMS Yeast Res. 2008, 8, 183-192. [CrossRef] [PubMed]

65. Pethybridge, S.J. Fungicide Resistance Monitoring in C. beticola; Cornell University: Geneva, NY, USA, 2017; Unpublished data.

66. Gugino, B.K.; Ludwig, J.W.; Abawi, G.S. Evaluation of fungicides for the control of pocket rot and leaf spot of table beet, 2007. Plant Dis. Manag. Rep. 2008, 2, V156.

67. McGrath, M.T. What are fungicides? Plant Health Instr. 2004. [CrossRef] 
68. Karaoglanidis, G.S.; Bardas, G. Control of benzimidazole- and DMI-resistant strains of Cercospora beticola with strobilurin fungicides. Plant Dis. 2006, 90, 419-424. [CrossRef]

69. Secor, G.A.; Rivera, V.V.; Khan, M.F.R.; Gudmestad, N.C. Monitoring fungicide sensitivity of Cercospora beticola of sugar beet for disease management decisions. Plant Dis. 2010, 94, 1272-1282. [CrossRef]

70. Bolton, M.D.; Birla, K.; Rivera-Varas, V.; Rudolph, K.D.; Secor, G.A. Characterization of CbCyp51 from field isolates of Cercospora beticola. Phytopathology 2012, 102, 298-305. [CrossRef] [PubMed]

71. Trueman, C.J.; Rosenzweig, N.; Somohano, P.; Hanson, L.E. First report of demethylase inhibitor fungicide resistance in Cercospora beticola from sugar beet in Ontario, Canada. New Dis. Rep. 2017, 36, 20. [CrossRef]

72. Wightwick, A.M.; Mollah, M.R.; Partington, D.L.; Allinson, G. Copper fungicide residues in Australian vineyard soils. J. Agric. Food Chem. 2008, 56, 2457-2464. [CrossRef] [PubMed]

73. Gent, D.H.; Mahaffee, W.F.; McRoberts, N.; Pfender, W. The use and role of predictive systems in disease management. Annu. Rev. Phytopathol. 2013, 51, 267-289. [CrossRef] [PubMed]

74. Khan, J.; del Rio, L.E.; Nelson, R.; Khan, M.F.R. Improving the Cercospora leaf spot management model for sugar beet in Minnesota and North Dakota. Plant Dis. 2007, 91, 1105-1108. [CrossRef]

75. Windels, C.E.; Lamey, H.A.; Dave, H.; Widner, J.; Knudsen, T.A. Cercospora leaf spot model for sugar beet in practice by an industry. Plant Dis. 1998, 82, 716-726. [CrossRef]

76. Rossi, V.; Battilani, P. CERCOPRI: A forecasting model for primary infections of Cercospora leaf spot of sugarbeet. EPPO Bull. 1991, 21, 527-531. [CrossRef]

77. Wolf, P.F.J.; Verreet, J.A. An integrated pest management system in Germany for the control of fungal leaf diseases in sugar beet. The IPM sugar beet model. Plant Dis. 2002, 86, 336-344. [CrossRef]

78. Jacobsen, B. Bacterial leaf spot. In Compendium of Beet Diseases and Other Pests; APS Press: St. Paul, MN, USA, 2009; ISBN 978-0-89054-365-8.

79. O'Brien, R.G.; Sparshott, P.E. Bacterial blight in Queensland beetroot crops. Australas. Plant Pathol. 1999, 28, 182. [CrossRef]

80. Ark, P.A.; Leach, L.D. Seed transmission of bacterial blight of sugar beet. Phytopathology 1946, 36, 549-553. [PubMed]

81. Riffaud, C.M.-H.; Morris, C.E. Detection of Pseudomonas syringae pv. aptata in irrigation water retention basins by immunofluorescence colony-staining. Eur. J. Plant Pathol. 2002, 108, 539-545. [CrossRef]

82. Pethybridge, S.J.; Kikkert, J.R. Control of Foliar Disease of Table Beet Using OMRI-Approved Products; Cornell University: Geneva, NY, USA, 2017; Unpublished data.

83. Pool, V.W.; McKay, M.B. Phoma betae on the leaves of sugar beet. J. Agric. Res. 1915, 4, 169-177.

84. Monte, E.; Garcia-Acha, I. Vegetative and reproductive structures of Phoma betae in vitro. Trans. Br. Mycol. Soc. 1998, 90, 233-245. [CrossRef]

85. Vaghefi, N.; Kikkert, J.R.; Pethybridge, S.J. Incidence and pathogenicity of Didymella americana on table beet in New York. Plant Health Prog. 2016, 17, 270-272. [CrossRef]

86. Edson, H.A. Seedling diseases of sugar beets and their relation to root-rot and crown-rot. J. Agric. Res. 1915, $4,135-168$.

87. Herr, L.J. Hot water treatment for elimination of seed-borne Phoma betae and other microbial contaminants from sugar beet seed. J. Am. Soc. Sugar Beet Technol. 1971, 16, 568-574. [CrossRef]

88. Mangan, A. New method for the detection of Pleospora bjoerlingii infection of sugar beet seed. Trans. Br. Mycol. Soc. 1971, 57, 169-172. [CrossRef]

89. Bugbee, W.M. A selective medium for the isolation and enumeration of Phoma betae in soil and seed. Phytopathology 1974, 64, 706-708. [CrossRef]

90. Bugbee, W.M.; Soine, O.C. Survival of Phoma betae in soil. Phytopathology 1974, 64, 1258-1260. [CrossRef]

91. Maude, R.B.; Vizor, A.S.; Shuring, C.G. The control of fungal seed borne diseases by means of a thiram seed soak. Ann. Appl. Biol. 1969, 64, 245-257. [CrossRef]

92. Abawi, G.S.; Crosier, D.C.; Cobb, A.C.; Becker, R.F. Root Rot of Table Beets in New York State; N.Y. Food Life Sci. Bull. No. 115; New York State Agricultural Experiment Station: Geneva, NY, USA, 1986.

93. Scott, P.T.; Martin, H.L.; Boreel, S.M.; Wearing, A.H.; Maclean, D.J. Molecular characterization, pathogenicity, and fungicide sensitivity of Pythium spp. from table beet (Beta vulgaris var. vulgaris) grown in the Lockyer Valley, Queensland. Australas. Plant Pathol. 2005, 34,361-368. [CrossRef]

94. Abada, K.A. Fungi causing damping-off and root rot on sugar beet and their biological control with Trichoderma harzianum. Agric. Ecosyst. Environ. 1994, 51, 333-337. [CrossRef] 
95. Martin, F.N.; Loper, J.E. Soilborne plant diseases caused by Pythium spp.: Ecology, epidemiology, and prospects for biological control. Crit. Rev. Plant Sci. 1999, 18, 111-181. [CrossRef]

96. Ohkura, M.; Abawi, G.S.; Smart, C.D.; Hodge, K.T. Diversity and aggressiveness of Rhizoctonia solani and Rhizoctonia-like fungi on vegetables in New York. Plant Dis. 2009, 93, 615-624. [CrossRef]

97. Harveson, R.M.; Nielsen, K.A.; Eskridge, K.M. Utilizing a preplant soil test for predicting and estimating root rot severity in sugar beet in the Central High Plains of the United States. Plant Dis. 2014, 98, 1248-1252. [CrossRef]

98. Ophel-Keller, K.; McKay, A.; Hartley, D.; Curran, J. Development of a routine DNA-based testing service for soilborne diseases in Australia. Australas. Plant Pathol. 2008, 37, 243-253. [CrossRef]

99. Fox, R.T.V. Rapid methods for diagnosis of soil-borne plant pathogens. Soil Use Manag. 2009, 6, $179-183$. [CrossRef]

100. Tegg, R.; Corkrey, R.; Herdina, H.; McKay, A.C.; Crump, N.S.; de Boer, R.F.; Wiechel, T.J.; Wilson, C.R. Modeling pathogen DNA content and visual disease assessment in seed tubers to inform disease in potato progeny root, stolon and tubers. Plant Dis. 2015, 99, 50-57. [CrossRef]

101. Hay, F.S.; Herdina, O.-K.K.; Hartley, D.; Pethybridge, S.J. Prediction of potato tuber damage by root-knot nematodes using soilborne DNA. Plant Dis. 2016, 100, 592-600. [CrossRef]

102. Gorny, A.M.; Hay, F.S.; Wang, X.; Pethybridge, S.J. Isolation of nematode DNA from $100 \mathrm{~g}$ of soil using $\mathrm{Fe}_{3} \mathrm{O}_{4}$ super paramagnetic nanoparticles. Nematology 2018, 20, 271-283. [CrossRef]

103. Jacobson, B. Scab. In Compendium of Beet Diseases and Pests; APS Press: St. Paul, MN, USA, 2009; ISBN 978-0-89054-365-8.

104. Braun, S.; Gevens, A.; Charkowski, A.; Allen, C.; Jansky, S. Potato common scab: A review of the causal pathogens, management practices, varietal resistance screening methods, and host resistance. Am. J. Potato Res. 2017, 94, 283-296. [CrossRef]

105. Harveson, R.M. Southern Sclerotium root rot. In Compendium of Beet Diseases and Pests; APS Press: St. Paul, MN, USA, 2009; ISBN 978-0-89054-365-8.

106. Pethybridge, S.J. Root Diseases of Table Beet; Cornell University: Geneva, NY, USA, 2018; Unpublished data.

107. Mullen, J. Southern blight, Southern stem blight, White mold. Plant Health Instr. 2001. [CrossRef] 